\title{
GMR
}

\section{Investigation on possible occurrence of somaclonal effects in zygotic and embryonic cotton structures based on agronomical traits}

\author{
T.C. Soares ${ }^{1}$, J.M.F.C. Carvalho' ${ }^{2}$ L.M. Lima², R.M.M. Freire'2, \\ C.R.C. Silva ${ }^{1}$, P.A. Melo Filho ${ }^{1}$ and R.C. Santos ${ }^{2}$ \\ ${ }^{1}$ Renorbio, Universidade Federal Rural de Pernambuco, Recife, PE, Brasil \\ ${ }^{2}$ Empresa Brasileira de Pesquisa Agropecuária, Campina Grande, PB, Brasil \\ Corresponding author: J.M.F.C. Carvalho \\ E-mail: julita.carvalho@embrapa.br \\ Genet. Mol. Res. 16 (3): gmr16039711 \\ Received April 24, 2017 \\ Accepted July 3, 2017 \\ Published July 28, 2017 \\ DOI http://dx.doi.org/10.4238/gmr16039711 \\ Copyright $(2017$ The Authors. This is an open-access article distributed under the terms of \\ the Creative Commons Attribution ShareAlike (CC BY-SA) 4.0 License.
}

\begin{abstract}
Zygotic and embryonic cotton structures were used in in vitro procedures to obtain stable plants. Zygotes $(24,48$, and $72 \mathrm{~h})$ and immature embryos (10 and 25 days after fertilization) were grown in MS medium supplemented with glucose, indoleacetic acid, kinetin, and activated charcoal. Regenerated seedlings were acclimatized and grown in $10-\mathrm{kg}$ pots for further phenological evaluation, based on agronomic traits and possible occurrence of somaclonal effects. We found that zygotes and immature embryos at 10 days did not develop physiological competence to allow regeneration of plants, based on adopted procedures. Stable plants were achieved with embryos at 25 days, with $68 \%$ of regeneration rate. The agronomical traits of these plants were similar to those obtained via seeds. Overall, the maturation cycle of cotton plants was 120 days after acclimation. No somaclonal effect, resulting from in vitro procedures was found in regenerated plants, based on agronomical traits evaluated in normal and regenerated plants.
\end{abstract}

Key words: Gossypium hirsutum L.; Zygotes; Immature embryos; Recalcitrance; Regeneration

Genetics and Molecular Research 16 (3): gmr16039711 


\section{INTRODUCTION}

Cotton (Gossypium hirsutum L.) is an important commodity worldwide and plays a significant role in textile agribusiness. The current contribution of cotton crop exceeds U\$20 billion, moving 180 million of persons dependent on fiber and seed markets (Freitas et al., 2014). Despite the economic importance, a strong cotton yield is widely dependent on genotype $\mathrm{x}$ environmental factors. The world market of seeds offers a range of robust cultivars with broad environmental adaptation and yield stability, allowing the selection of the best ideotypes to different kind of farmers.

Some environmental factors exert a strong influence on cotton development, emphasizing water and salt stresses and damages caused by pests (Conaty et al., 2012; Echer et al., 2014). Depending on intensity, they may cause serious disturbances in plant physiology, such as nutritional deficiency and hormonal imbalance, leading to abscission of leaves and reproductive structures (Silva et al., 2011). According to Krieg (2005), shedding of young buds and bools in the cotton crop can take up to $65 \%$, when plants are facing on severe biotic or abiotic stress conditions. This rate could be dangerous when dealing with germplasm preservation.

The maintenance and preservation of germplasm are basic strategies for the establishment of a breeding program. In recalcitrant species, the adoption of conservation practices is indispensable for germplasm safety. The current tools of modern biotechnology have contributed markedly to rescue germplasm through several in vitro techniques, by using hormonal stimuli. These techniques are based on cell totipotency that refers to the capacity of cell organization to generate a whole plant, without genetic recombination (Neelakandan and Wang, 2012). The regeneration of plants can be accomplished via organogenesis or embryogenesis; in the last case, by somatic or zygotic procedures (Kikuchi et al., 2013).

The in vitro crop of zygotic embryos is a valuable tool to rescue germplasm; however, the success rate depends on the complexity of endogenous and exogenous factors, such as culture media, exogenous growth regulators, age of tissues, among others (Polanco and Ruiz, 2001; Umehara et al., 2007; Uma et al., 2011). The procedures that do not involve de-differentiation from explant (callus formation) and subsequent re-differentiation are more likely to provide satisfactory results. However, the methodologies are not suitable for all species. In recalcitrant species, such as cotton, this process may be limited or even unfeasible, hampering the regeneration of interesting accessions (Soares et al., 2014).

Despite large benefits obtained by in vitro procedures, clonally propagated plants often exhibited some level of somaclonal, either genetic or epigenetic in origin, displayed among plants derived from cell culture involving the use of somatic plant cells. This is because changes in tissue culture involve disorganized growth at various levels, ranging from systems that lead to disturbing at cell organization. Epigenetic modifications take place in the chromatin allowing cells to maintain distinct characteristics despite containing the same genetic material (Camas et al., 2014). The epigenetic factors emphasize the interaction between genes and the environment, whose modifications occur in an individual's genome that ultimately influence the organism's development and the process of its heredity (Springer, 2013). Such process reflects the adaptation of cells to a different environment, which includes the response to signals that may trigger switches in the developmental program.

In plant regeneration obtained by in vitro procedures, epigenetic variations have been reported during cell differentiation and de-differentiation (Miguel and Marum, 2011; Yang et al., 2013). The processes of de-differentiation and re-differentiation may involve both qualitative

Genetics and Molecular Research 16 (3): gmr16039711 
and quantitative changes in the genome, and different DNA sequences may be amplified or deleted during these changes (Lee and Phillips, 1988). Somaclonal variation, therefore, can arise from somatic mutations already present in the donor plant (Karp, 1994; Bairu et al., 2011) and undesired effects of adaptive adjustments may compromise the objectives for which the plant cells or tissues were cropped. Therefore, it is necessary to follow up the phenotype of regenerated plants, at least the main agronomic traits, to discard previously atypical plants that can further compromise the genetic uniformity of matrix cultivar. Among factors that determine the frequency of variation during crop tissue procedures, the propagation methods, genotype, and growth regulators are more reported (Uma et al., 2011; Miguel and Marum, 2011; Yang et al., 2013). To investigate possible somaclonal variations arising from zygotic structures and immature embryos grown in vitro, this study was carried out, based on comparisons of agronomic traits in stock and regenerated cotton plants.

\section{MATERIAL AND METHODS}

\section{In vitro procedures}

Seeds of cotton cv. BRS $8 \mathrm{H}$ were grown in pots $(10 \mathrm{~L})$ containing fertilized soil (20:60:20, v/v/v, NPK) and daily watered, in a greenhouse. At blooming, young and fertilized bolls were collected in five growth stages and disinfected ( $0.5 \%$ sodium hypochlorite). Zygotes (24, 48, and $72 \mathrm{~h}$ ) and immature embryos (10 and 25 days after fertilization) were aseptically excised and subsequently inoculated into bottles $(250 \mathrm{~mL})$ containing MS medium (Murashige and Skoog, 1962), $\mathrm{pH} 5.7$, supplemented with glucose (3\%), indoleacetic acid (IAA, $0.1 \mathrm{mg} / \mathrm{L})$, Kinetin (Kin, $0.5 \mathrm{mg} / \mathrm{L})$ and activated charcoal $(1.0 \mathrm{~g} / \mathrm{L})($ Carvalho et al., 2003). Fifteen structures/bottle were used for zygote treatments, whereas five were used to immature embryos. Assays were performed in five replicates for each treatment.

The samples were incubated in a growth chamber (Biofoco, Brazil), in the dark ( $25 \pm$ $2^{\circ} \mathrm{C}$ ) until the appearance of radicle (about 30 days). Then, seedlings were transferred to glass tubes $(30 \mathrm{~mL})$ containing hormone-free MS medium, and incubated in the growth chamber $\left(25 \pm 2{ }^{\circ} \mathrm{C}, 16\right.$-h light and light intensity of $\left.40 \mu \mathrm{mol} \cdot \mathrm{m}^{-2} \cdot \mathrm{s}^{-1}\right)$, for 15 days.

Seedling showing secondary leaves and roots were transferred to polypropylene pots $(100 \mathrm{~mL})$ containing sterile vermiculite and substrate $(1: 1, \mathrm{v} / \mathrm{v})$ (Plantmax, Brazil), and incubated in the growth chamber $\left(25 \pm 2{ }^{\circ} \mathrm{C}, 16\right.$-h light and light intensity of $\left.40 \mu \mathrm{mol} \cdot \mathrm{m}^{-2} \cdot \mathrm{s}^{-1}\right)$ for 7 days. Then, they were acclimatized in the greenhouse $\left(28 \pm 2{ }^{\circ} \mathrm{C}, 12: 12\right.$-h light/dark).

\section{Assay in the greenhouse}

To investigate possible somaclonal variation in plants (cv. BRS $8 \mathrm{H}$ ) due to in vitro procedures, regenerated plants (Population 1) were evaluated phenotypically based on agronomic traits, compared to plants grown by seeds (Population 2). Plants from Population 1 (30 days of acclimatization) were transferred to pots $(10 \mathrm{~L})$ containing fertilized soil (20:40:20, $\mathrm{v} / \mathrm{v} / \mathrm{v}, \mathrm{NPK}$ ) and daily watered. To try to conciliate the phenological age of both populations, seeds of Population 2 were sown 30 days before acclimatization of Population 1. Plants were cropped in the same conditions as Population 1. Watering was performed by sprinkler irrigation keeping the pot capacity. Each population was composed of 17 individuals and plants were kept free of insects and weeds. The ranges of temperature and relative humidity recorded

Genetics and Molecular Research 16 (3): gmr16039711 
during the assay in the greenhouse were $32-35^{\circ} \mathrm{C}$ and $58-66 \%$.

The follows traits were evaluated: the plant height, the number of bolls, the weight of mature bolls, cycle, and oil content. All data were recorded individually in each plant of two populations. The oil content was estimated in seeds $(20 \mathrm{~g})$, by nuclear magnetic resonance from each plant. The calibration curve conditions were previously established, and oil contents were estimated from the total mass of plant seeds. Five repetitions were taken from each plant. The considerations were inferred from averages of each population.

\section{RESULTS AND DISCUSSION}

\section{Regeneration of zygotes and immature embryos}

Based on the procedures adopted in this study, we found that tissues from zygotes and immature embryos collected at $24 \mathrm{~h}$ to a 10-day interval did not get physiological competencies to respond to hormonal stimuli after 30 days of cropping. Only embryos collected with 25 days generated viable seedlings. An oxidative process occurred similarly in zygote treatments despite the addition of $1.0 \mathrm{~g} / \mathrm{L}$ activated charcoal (Figure 1A). This element is quite important in growth medium because it reduces oxidation of tissues and also promotes absorption of exudates released by explants (George, 1996). We concluded that the concentration used in this assays was not enough to avoid oxidation in tissues. According to Pollock and Jensen (1964), the pattern of early cell divisions in cotton zygote is irregular and in vitro regeneration of these structures becomes limited due to intrinsic conditions of explant, such as cells still undifferentiated, absence of endosperm and the reserves of zygote that decrease during early cell division (4 to 5 days after acclimation).

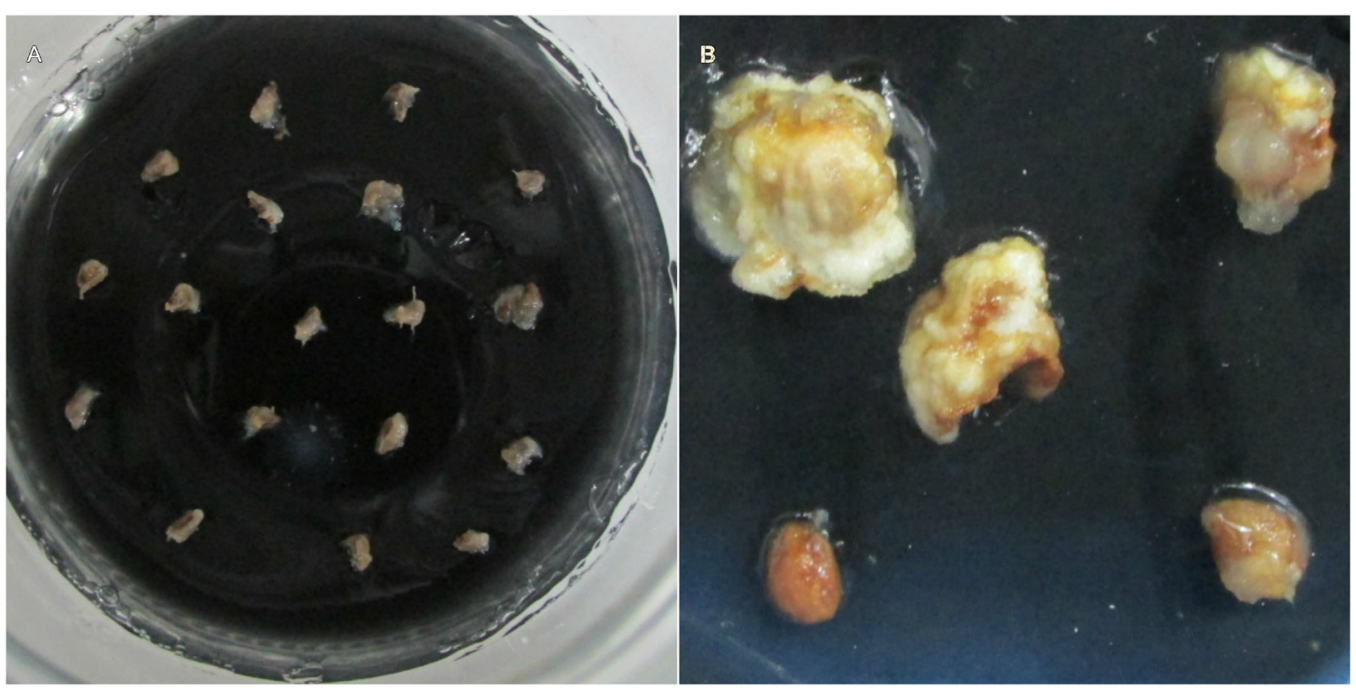

Figure 1. A. Zygotes with $72 \mathrm{~h}$ showing oxidation after 30 days of the crop. B. Callogenesis and oxidation of immature embryos 10 days after fertilization. 
Shen et al. (2011) report that rescue of zygotes or immature embryos depends widely on components of culture medium to promote morphogenesis of undifferentiated cells (callus). In recalcitrant species, such cotton, regeneration is a difficult process in some genotypes due to natural inability to acquire morphogenic competence, during differentiation procedures. The stimulus depends primarily on adjustments in hormonal balance and successive subcultures of calli. Therefore, we understand that the procedures adopted here for zygotes and immature embryos require better adjustments to get success on the rescue of these tissues.

Regarding immature embryos, viable seedlings were achieved only with embryos excised 25 days after fertilization (Figure 2), with a regeneration rate of $68 \%$ after acclimatization of seedlings (Table 1). This rate was quite satisfactory and benefited due to the autotrophic capacity of embryos to respond better to components of culture media. The 10 days after fertilization embryos were unviable and did not show embryogenic calli (Figure 1B).

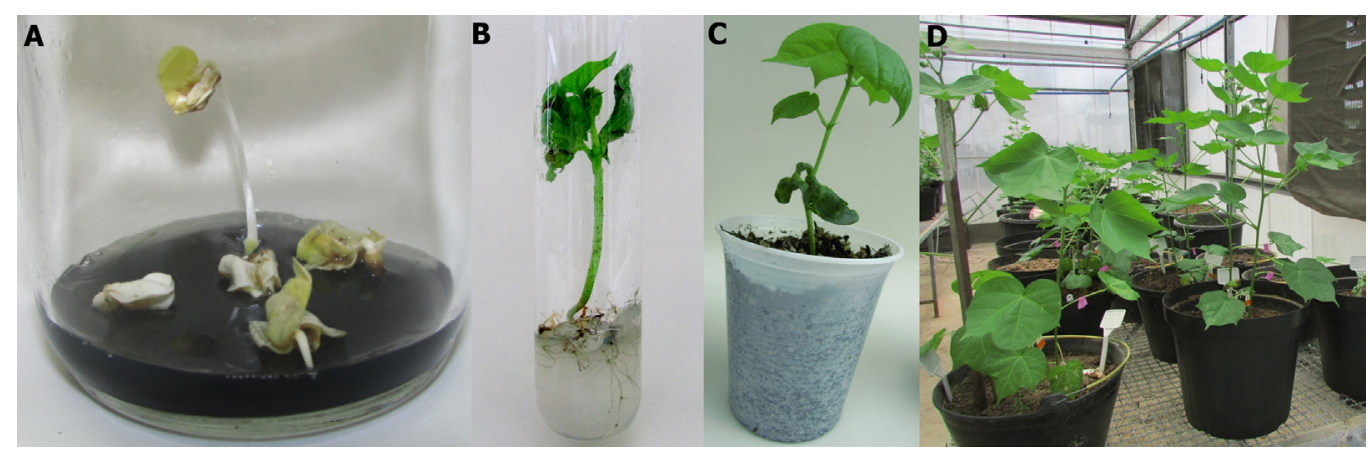

Figure 2. Plants regenerated from immature embryos 25 days after fertilization. A. Seedlings showing radicle and hypocotyl developed after 20 days of cropping in MS medium supplemented with $0.1 \mathrm{mg} / \mathrm{L} \mathrm{IAA}+0.5 \mathrm{mg} / \mathrm{L} \mathrm{Kin}+$ $1.0 \mathrm{~g} / \mathrm{L}$ activated charcoal; B. seedlings grown in MS medium without growth regulators; C. plants acclimatized in sterile substrate; D. plants regenerated and acclimatized in the greenhouse.

Table 1. Regeneration rates of zygotes and immature embryos from cotton genotype (cv. BRS 8H) cropped in vitro.

\begin{tabular}{l|c|c|c}
\hline \multirow{2}{*}{ Treatment } & Sample (N) & \multicolumn{2}{|c}{ Regeneration } \\
\cline { 3 - 4 } & & 0 & Rate (\%) \\
\hline Z 24 h & 75 & 0 & 0 \\
\hline Z 48 h & 75 & 0 & 0 \\
\hline Z 72 h & 75 & 0 & 0 \\
\hline IE 10 days & 25 & 17 & 08 \\
\hline IE 25 days & 25 & & \\
\hline
\end{tabular}

$\mathrm{Z}=$ zygotes; $\mathrm{IE}=$ immature embryos.

\section{Phenology of plants in the greenhouse}

The seventeen plants obtained from embryos 25 days after fertilization (Population 1) were grown in the greenhouse, adopting the same management as to Population 2 (cv. BRS $8 \mathrm{H}$ grown by seeds). We found that both populations had normal growth during the life cycle and no significant difference was found in plants, at all (Figure 2D). The average cycle of Population 1 was 125 days after anthesis. Whereas acclimatization lasted 30 days, we consider that both populations had close phenological cycles (Population $2=158$ days). The 
agronomic traits registered in both populations are in Table 2 . The values found individually in plants were too close, so that the means were quite similar in both populations, suggesting no occurrence of any somaclonal variations in regenerated plants, based on the traits evaluated.

Table 2. Agronomic traits registered individually in cotton plants obtained via in vitro cropping and by seeds.

\begin{tabular}{l|c|c|c|c|c|c|c|c|c|c|c}
\hline Pop 1 & PH & NB & WB & C & O & Pop 2 & PH & NB & WB & C & O \\
\hline R1 & 101 & 15 & 5.7 & 124 & 19.8 & S1 & 98 & 12 & 6.2 & 157 & 20.3 \\
\hline R2 & 99 & 12 & 5.9 & 124 & 19.9 & S2 & 98 & 12 & 5.6 & 157 & 19.9 \\
\hline R3 & 106 & 15 & 6.1 & 125 & 21.1 & S3 & 102 & 11 & 5.9 & 156 & 21.1 \\
\hline R4 & 98 & 12 & 6.2 & 126 & 21.2 & S4 & 99 & 12 & 6.4 & 158 & 21.3 \\
\hline R5 & 98 & 12 & 5.9 & 126 & 21.0 & S5 & 106 & 15 & 5.7 & 159 & 19.8 \\
\hline R6 & 101 & 13 & 5.5 & 124 & 21.2 & S6 & 104 & 15 & 6.5 & 159 & 19.3 \\
\hline R7 & 105 & 12 & 5.9 & 124 & 20.3 & S7 & 98 & 13 & 5.9 & 158 & 20.3 \\
\hline R8 & 98 & 13 & 6.3 & 124 & 20.6 & S8 & 103 & 14 & 6.3 & 158 & 20,2 \\
\hline R9 & 96 & 14 & 6.2 & 125 & 20.5 & S9 & 99 & 15 & 6.1 & 156 & 21.0 \\
\hline R10 & 99 & 15 & 6.5 & 125 & 20.3 & S10 & 99 & 15 & 5.9 & 156 & 21.1 \\
\hline R11 & 101 & 12 & 5.9 & 125 & 19.9 & S11 & 103 & 13 & 6.0 & 157 & 20.9 \\
\hline R12 & 102 & 12 & 6.1 & 126 & 19.9 & S12 & 104 & 14 & 6.2 & 157 & 20.8 \\
\hline R13 & 104 & 13 & 6.1 & 124 & 19.8 & S13 & 101 & 12 & 6.5 & 158 & 21.2 \\
\hline R14 & 101 & 14 & 6.3 & 126 & 20.6 & S14 & 105 & 12 & 5.8 & 158 & 21.0 \\
\hline R15 & 101 & 14 & 6.2 & 126 & 21.0 & S15 & 99 & 14 & 6.0 & 159 & 19.9 \\
\hline R16 & 99 & 15 & 5.9 & 125 & 21.1 & S16 & 100 & 11 & 6.2 & 158 & 21.0 \\
\hline R17 & 98 & 14 & 5.9 & 125 & 19.9 & S17 & 99 & 11 & 6.1 & 158 & 19.9 \\
\hline Mean & 100 & 13 & 6.0 & 125 & 20.5 & Mean & 101 & 13 & 6.1 & 158 & 20.5 \\
\hline
\end{tabular}

$\mathrm{PH}=$ plant height $(\mathrm{cm}) ; \mathrm{NB}=$ number of bolls; $\mathrm{WB}=$ weight of mature bolls $(\mathrm{g}) ; \mathrm{C}=$ cycle (days); $\mathrm{O}=$ oil content in seeds (\%). Pop 1 - plants obtained from regenerated embryos via in vitro cropping; Pop 2 - plants obtained from seeds.

Somaclonal variation in commercial species generated by in vitro crop has been widely reported in the literature as well as their use to plant breeding, as a way of generating variability (Miguel and Marum, 2011; Yang et al., 2013; Springer, 2013). In immature organs, the effects of somaclonal variation are unpredictable considering that the cell complex is still in the intensive process of differentiation. In recalcitrant species, the understanding of the morphogenic response in vitro requires knowledge of the function of genes directly involved in cell competence route, to assist the adoption of strategies to improve the morphogenesis (Kikuchi et al., 2013; Zhu et al., 2014; Zheng and Perry, 2014). The genetic programs that control the embryo development in zygotic and somatic embryogenesis display several similar routes, although the mechanisms determining the induction phase of these two processes are quite different. The development of zygotic embryo begins with the formation of the zygote following fertilization, while somatic cells acquire embryogenic competence as a result of different chemical and physical stimuli (Karami et al., 2009). According to Skirvin et al. (1994), the inductions generated by somatic embryogenesis procedures can reveal alterations between cells, tissues, and organs thereby creating variation within cultures, or among the somaclones, that may be physically different from matrix plants by which the culture was derived. Maintaining genetic integrity of matrix plants is the most crucial aspect in plant propagation, and components of growth media are important factors that can promote somaclonal variation, especially the type and availability of growth regulators.

\section{CONCLUSIONS}

Based on media components used in this study, especially growth regulators, no alterations were found in regenerated plants from 25 days after fertilization, meaning that the 
genetic integrity of cv. BRS $8 \mathrm{H}$ was maintained, at least, in traits evaluated. However, it is worth noting that despite the importance of uniformity of regenerated plants, variations arising from asexual propagation could be an interesting alternative for further use in crop breeding depending on the advantage that the trait brings to the program.

\section{ACKNOWLEDGMENTS} respectively.

The authors thank Embrapa and CAPES for financial support and scholarship,

\section{REFERENCES}

Bairu MW, Aremu AO and Van SJ (2011). Somaclonal variation in plants: causes and detection methods. Plant Growth Regul. 63: 147-173. https://doi.org/10.1007/s10725-010-9554-x

Camas RU, Solís GR, Aké FD and Peña DL (2014). In vitro culture: an epigenetic challenge for plants. Plant Cell Tiss. Org. 118: 187-201.

Carvalho JMFC, Júnior de Souza RL, Lopes KP and Santos JW (2003). Otimização da metodologia da regeneração de embriões imaturo de algodão. Embrapa Algodão, Comunicado Técnico, Campina Grande.

Conaty WC, Burke JJ, Mahan JR, Neilsen JE, et al. (2012). Determining the optimum plant temperature of cotton physiology and yield to improve plant-based irrigation scheduling. Crop Sci. 52: 1828-1836. https://doi.org/10.2135/ cropsci2011.11.0581

Echer FR, Oosterhuis DM, Loka D and Rosolem CA (2014). High night temperatures during the floral bud and flowering stages increase the abscission of reproductive structures in cotton. J. Agron. Crop Sci. 2: 191-198. https://doi. org $/ 10.1111 / \mathrm{jac} .12056$

Freitas GA, Santos ACM, Faria AJG, Souza MAS, et al. (2014). Produção do algodoeiro em função da adubação fosfatada utilizando fertilizante Basiduo. J. Bioenerg. Food Sci. 1: 78-86.

George EF (1996). Establishment. In: Plant propagation by tissue culture. Exegetics, Edington, 190-320.

Karami O, Aghavaisi B and Mahmoudi Pour A (2009). Molecular aspects of somatic-to-embryogenic transition in plants. J. Chem. Biol. 2: 177-190. https://doi.org/10.1007/s12154-009-0028-4

Karp A (1994). Origins, causes and uses of variation in plant tissue cultures. In: Plant cell and tissue culture (Vasil IK and Thorpe TA, eds.). Kluwer Academic Publishers, Dordrecht.

Kikuchi A, Asahina M, Tanaka M, Satoh S, et al. (2013). Acquisition of embryogenic competency does not require cell division in carrot somatic cell. J. Plant Res. 126: 243-250. https://doi.org/10.1007/s10265-012-0517-3

Krieg D (2005). Nutrient/water input - Key to high-yielding cotton. Fluid J. 1: 1-3.

Lee M and Phillips RL (1988). The Chromosomal basis of somaclonal variation. Annu. Rev. Plant Physiol. Plant Mol. Biol. 39: 413-437. https://doi.org/10.1146/annurev.pp.39.060188.002213

Miguel C and Marum L (2011). An epigenetic view of plant cells cultured in vitro: somaclonal variation and beyond. $J$. Exp. Bot. 62: 3713-3725. https://doi.org/10.1093/jxb/err155

Murashige T and Skoog F (1962). A revised medium for rapid growth and bioassays with tobacco tissue culture. Physiol. Plant. 15: 473-497. https://doi.org/10.1111/j.1399-3054.1962.tb08052.x

Neelakandan AK and Wang K (2012). Recent progress in the understanding of tissue culture-induced genome level changes in plants and potential applications. Plant Cell Rep. 31: 597-620. https://doi.org/10.1007/s00299-011-1202-z

Polanco MC and Ruiz ML (2001). Factors that affect plant regeneration from in vitro culture of immature seeds in four lentil cultivars. Plant Cell Tiss. Org. 66: 133-139.

Pollock EG and Jensen WA (1964). Cell development during early embryogenesis in Capsella and Gossypium. Am. J. Bot. 51: 915-921. https://doi.org/10.2307/2440240

Shen X, Gmitter FG, Jr. and Grosser JW (2011). Immature embryo rescue and culture. Methods Mol. Biol. 710: 75-92. https://doi.org/10.1007/978-1-61737-988-8 7

Silva IPF, Junior JFS, Araldi R, Tanaka AA, et al. (2011). Estudo das fases fenológicas do algodão (Gossypium hirsutum L.). Rev. Cient. Elet. Agron. 20: 1-10.

Skirvin RM, McPheeters KD and Norton M (1994). Sources and frequency of somaclonal variation. HortScience 29: 1232-1237.

Soares TC, Sales FMS, Santos JW and Carvalho JMFC (2014). Quitosana e fitorreguladores na indução da organogênese

Genetics and Molecular Research 16 (3): gmr16039711 
direta em cultivar de algodão colorido. Rev. Bras. Eng. Agric. Ambient. 18: 839-843. https://doi.org/10.1590/18071929/agriambi.v18n08p839-843

Springer NM (2013). Epigenetics and crop improvement. Trends Genet. 29: 241-247. https://doi.org/10.1016/j. tig.2012.10.009

Uma S, Lakshmi S, Saraswathi MS, Akbar A, et al. (2011). Embryo rescue and plant regeneration in banana (Musa spp.). Plant Cell Tiss. Org. 105: 105-111.

Umehara M, Ikeda M and Kamada H (2007). Endogenous factors that regulate plant embryogenesis: Recent Advances. Jpn. J. Plant Sci. 1: 1-6.

Yang X, Wang L, Yuan D, Lindsey K, et al. (2013). Small RNA and degradome sequencing reveal complex miRNA regulation during cotton somatic embryogenesis. J. Exp. Bot. 64: 1521-1536. https://doi.org/10.1093/jxb/ert013

Zheng Q and Perry SE (2014). Alterations in the transcriptome of soybean in response to enhanced somatic embryogenesis promoted by orthologs of Agamous-like15 and Agamous-like18. Plant Physiol. 164: 1365-1377. https://doi. org/10.1104/pp.113.234062

Zhu S, Wang J, Ye J, Zhu A, et al. (2014). Isolation and characterization of LEAFY COTYLEDON 1-LIKE gene related to embryogenic competence in Citrus sinensis. Plant Cell Tiss. Org. 119: 1-13.

Genetics and Molecular Research 16 (3): gmr16039711 